\title{
Approaching challenging necks by EVAR
}

Tulio Pinho Navarro*

Proximal neck is a key point in determining longterm success of endovascular aortic repair ${ }^{1-3}$. The most common instructions for graft use recommend a neck length of $1.5 \mathrm{~cm}$ and an angulation of up to $60^{\circ}$. Therefore, a short $(<1.5 \mathrm{~cm})$ and angulated $\left(>60^{\circ}\right)$ neck is an off-label indication for most devices ${ }^{1}$, leading to high rates of treatment failure. However, some approaches may improve results in high-risk patients.

Perioperative endovascular maneuvers to achieve effective sealing of endografts in challenging proximal necks include high-pressure ballooning, deployment of proximal cuff, slow and controlled deployment, use of the bending-the-wire technique to realign the axis of the aneurysm and of the neck, and the use of appropriate C-arm angulation ${ }^{4}$.

Some strategies are available to overcome angulated necks, e.g., deployment of Palmaz stents ${ }^{5}$. However, in mid-term follow-up, patients were found to be at high risk for graft-related events ${ }^{6}$. The use of thoracic endografts could be considered for proximal sealing prior to deploying the bifurcated graft ${ }^{7}$. Finally, extending the proximal neck using the hybrid approach can be achieved by renal debranching ${ }^{8,9}$ or proximal aortic neck banding ${ }^{10}$.

The chimney technique is an alternative to fenestrated/branched endografts because it is simple, has a low cost, and is readily available. A systematic review ${ }^{11}$ has concluded that this complementary technique has good short-term results, but long-term outcomes remain the subject of significant concern ${ }^{12}$.

Fenestrated/branched endografts may allow implantation at a more favorable level for the proximal landing zone ${ }^{13}$. A meta-analysis ${ }^{14}$ concluded that it is a viable alternative to open repair. However, there is no level-1 evidence available, and current findings are weak, leaving many unanswered questions.

Currently, there are some new devices, based on novel concepts. The Nellix endoprosthesis, for example, has its use intended for favorable and adverse anatomy. Despite early promising results, longer-term studies are needed ${ }^{15}$. Endostapling and endoanchoring systems seem to be very promising and have proven to be feasible and safe ${ }^{16,17}$, reducing the rates of endoleak type $1 \mathrm{~A}$ and endograft migration in a systematic review ${ }^{18}$. Notwithstanding, results are not conclusive, and no randomized controlled trials have been published ${ }^{18}$.

From a different perspective, new generation devices represent an evolution of the endografts. The Endurant endograft was designed with the goal of extending its applicability ${ }^{19}$ to short necks $(1.0 \mathrm{~cm})$ and high angulations $\left(75^{\circ}\right)$. Early reports ${ }^{19}$ have concluded that it can be deployed safely, even in highly angulated anatomies (mean $80.8^{\circ}$ angulation $)^{20}$, with satisfactory results, but mid- and long-term data are awaited to verify durability. The new repositionable C3 Excluder endograft allows proximal accurate and controlled deployment with the ability to reposition the graft, reducing the need for additional cuffs, but again, no long-term data are available $^{21}$. Finally, an initial study with the Aorfix endovascular endograft supported its application in highly angulated necks $\left(90^{\circ}\right)^{22}$. Once again, however, no mid- or long-term results are available.

In conclusion, endograft technology has substantially improved ${ }^{23}$. However, unfavorable anatomy continues to represent a major drawback, restraining endovascular procedures. More substantial data and stronger, evidence-based results are needed. Appropriate patient selection and operator training will allow improvement of long-term results ${ }^{23}$. 


\section{REFERENCES}

1. Schanzer A, Greenberg RK, Hevelone N, et al. Predictors of Abdominal Aortic Aneurysm Sac Enlargement After Endovascular Repair. Circulation. 2011;123:2848-2855. PMid:21478500. http:// dx.doi.org/10.1161/CIRCULATIONAHA.110.014902

2. AbuRahma AF, Campbell J, Stone PA, et al. Early and late clinical outcomes of endovascular aneurysm repair in patients with an angulated neck. Vascular. 2010;18:93-101. http://dx.doi. org/10.2310/6670.2010.00010

3. Coscas R, Becquemin JP, Majewski M, et al. Management of perioperative endoleaks during endovascular treatment of juxtarenal aneurysms. Ann Vasc Surg. 2012;26:175-84. PMid:22078306. http://dx.doi.org/10.1016/j.avsg.2010.10.021

4. Ghouri MA, Dougherty KG, Krajcer Z. Technical tips for endovascular treatment of abdominal aortic aneurysms with challenging infrarenal neck anatomy using the Excluder endoprosthesis. J Endovasc Ther. 2010;17:705-11. PMid:21142477. http://dx.doi.org/10.1583/10-3170.1

5. Farley SM, Rigberg D, Jimenez JC, et al. A retrospective review of Palmaz stenting of the aortic neck for endovascular aneurysm repair. J Vasc Surg. 2011;25:735-9. PMid:21665423. http://dx.doi. org/10.1016/j.avsg.2011.02.042

6. Chung J, Corriere MA, Milner R, et al. Midterm results of adjunctive neck therapies performed during elective infrarenalaortic aneurysm repair. J Vasc Surg. 2010;52:1435-41. PMid:21146743. http://dx.doi.org/10.1016/j.jvs.2010.06.163

7. Silingardi R, Tasselli $S$, Gennai $S$, et al. Thoracic endograft for abdominal aortic aneurysms, an unusual application for severe neck angulation: case report and literature review. Vascular. 2010;18:102-5. http://dx.doi.org/10.2310/6670.2009.00054

8. Lerussi G, O'Brien N, Sessa C, et al. Hepatorenal bypass allowing fenestrated endovascular repair of juxtarenal abdominal aortic aneurysm: a case report. J Vasc Endovasc Surg. 2010;39:305-7. PMid:19945314. http://dx.doi.org/10.1016/j.ejvs.2009.11.012

9. Fergany A, Kolettis P, Novick AC. The contemporary role of extra-anatomical surgical renal revascularization in patients with atherosclerotic renal artery disease. J Urol. 1995;153:1798-801. http://dx.doi.org/10.1016/S0022-5347(01)67311-7

10. Utíkal P, Köcher M, Bachleda P, et al. Banding in aortic stent-graft fixation in EVAR. Biomed. 2004;148:175-178.

11. Antoniou GA, Schiro A, Antoniou AS, et al. Chimney technique in the endovascular management of complex aortic disease. Vascular. Vascular. 2012;20:251-61. PMid:22983540. http://dx.doi. org/10.1258/vasc.2011.ra0056

12. Moulakakis KG, Mylonas SN, Avgerinos E, et al. The chimney graft technique for preserving visceral vessels during endovascular treatment of aortic pathologies. J Vasc Surg. 2012;55:1497-503. PMid:22236883. http://dx.doi.org/10.1016/j.jvs.2011.10.009
13. Chuter TA. Fenestrated and branched stent-grafts for thoracoabdominal, pararenal and juxtarenal aortic aneurysm repair. Semin Vasc Surg. 2007;20:90-6. PMid:17580246. http:// dx.doi.org/10.1053/j.semvascsurg.2007.04.006

14. Cross J, Gurusamy K, Gadhvi V, et al. Fenestrated endovascular aneurysm repair. Br J Surg. 2012;99:152-9. PMid:22183704. http:// dx.doi.org/10.1002/bjs.7804

15. Krievins DK, Holden A, Savlovskis J, et al. EVAR using the Nellix Sac-anchoring endoprosthesis: treatment of favourable and adverse anatomy. Eur J Vasc Endovasc Surg. 2011;42:38-46. PMid:21497521. http://dx.doi.org/10.1016/j.ejvs.2011.03.007

16. Donas KP, Torsello G. Midterm results of the Anson Refix endostapling fixation system for aortic stent-grafts. J Endovasc Ther. 2010 Jun;17(3):320-3. PMid:20557169. http://dx.doi. org/10.1583/09-2992.1

17. Perdikides T, Melas N, Lagios K, et al. Primary endoanchoring in the endovascular repair of abdominal aortic aneurysms with an unfavorable neck. J Endovasc Ther. 2012 Dec;19(6):707-1. PMid:23210865. http://dx.doi.org/10.1583/JEVT-12-4008R.1

18. Bail DH, Walker T, Giehl J. Vascular Endostapling Systems for Vascular Endografts (T)EVAR - Systematic Review: Current State. Vasc Endovascular Surg. 2013 Feb 20. PMid:23427286. http:// dx.doi.org/10.1177/1538574413478474

19. Verhagen HJ, Torsello G, De Vries JP, et al. Endurant stent-graft system: preliminary report on an innovative treatment for challenging abdominal aortic aneurysm. J Cardiovasc Surg. 2009;50:153-8.

20. Bastos-Gonçalves F, De Vries JP, Van Keulen JW, et al. Severe proximal aneurysm neck angulation: early results using the Endurant stentgraft system. Eur J Vasc Endovasc Surg. 2011;41:193-200. PMid:21145268. http://dx.doi.org/10.1016/j. ejvs.2010.11.001

21. Verhoeven EL, Oikonomou K, Mohner B, et al. First experience with the new repositionable $\mathrm{C} 3$ excluder stent-graft. J Cardiovasc Surg. 2011;52:637-42.

22. Weale AR, Balasubramaniam K, Macierewicz J, et al. Outcome and safety of Aorfix TM stent graft in highly angulated necks - a prospective observational study. Eur J Vasc Endovasc Surg. 2011;41:337-43. PMid:21145264. http://dx.doi.org/10.1016/j. ejvs.2010.11.008

23. De Rango P. New-generation devices for highly angulated aortic necks: to bury or to praise Endovascular Aneurysm Repair (EVAR)? Eur J Vasc Endovasc Surg. 2011;41:344-5. PMid:21194984. http:// dx.doi.org/10.1016/j.ejvs.2010.11.022

Correspondence Tulio Pinho Navarro

Av. Brasil, 1438/1405 - Bairro Funcionários CEP 30140-003 - Belo Horizonte (MG), Brazil E-mails: tulio.navarro@gmail.com; tulio.navarro@gmail.com

Author's information

${ }^{*} \mathrm{MD}$, PhD, vascular surgeon and professor of Surgery, Federa University of Minas Gerais, Panamerican Circulation Institute. 